\title{
Effects of the colonial cyanobacterium Trichodesmium spp. on bacterial activity
}

\author{
Florent Renaud ${ }^{1,2}$, Olivier Pringault ${ }^{1}$, Emma Rochelle-Newall ${ }^{1, *}$ \\ ${ }^{1}$ Centre IRD Noumea, BP A5, Promenade Roger Laroque, 98848 Nouméa Cedex, New Caledonia \\ ${ }^{2}$ Present address: International Atomic Energy Agency, Marine Environment Laboratory (IAEA-MEL), \\ 4 Quai Antoine 1er, 98000 Monaco, Principality of Monaco
}

\begin{abstract}
We measured rates of particulate and dissolved primary production (DOCp) as well as bacterial production (BP) in order to determine the effect of freshly produced photosynthates on heterotrophic bacteria. During a 1 mo study carried out on samples from the southwestern lagoon of New Caledonia, we observed 2 different phytoplanktonic communities. The first was a mixed community, dominated by diatoms and with a low abundance of Trichodesmium spp. (10\% total phytoplankton cells) and the second community was dominated by Trichodesmium spp. (up to $98 \%$ total phytoplankton cells). Chlorophyll a normalised total (particulate + dissolved) primary production rates were twice as high in the mixed community compared to the Trichodesmium spp. dominated community. The percentage of extracellular release (PER), calculated as the percentage of DOCp divided by total primary production (TOCp), reached $8 \%$ in the mixed community; in contrast, rates were much lower in the Trichodesmium spp. community and remained close to $1 \%$. In terms of BP, activities were higher in the mixed community and were generally higher in light incubations than in the dark. In contrast, in the Trichodesmium spp. dominated community, bacterial activity was much lower and decreased with increasing Trichodesmium spp. abundance. This decrease in bacterial activity could not be explained by a decrease in bacterial abundance. This suggests that the proportion of active bacteria was much lower during the Trichodesmium spp. bloom.
\end{abstract}

KEY WORDS: Dissolved primary production · Bacterial-phytoplankton coupling $\cdot$ Bacterial production Resale or republication not permitted without written consent of the publisher

\section{INTRODUCTION}

In aquatic systems, the importance of the microbial loop in the flow of carbon through the system predicts that there should be at least some degree of coupling between primary producers and bacterial production (BP). During photosynthesis, phytoplankton produce and release a range of dissolved organic carbon (DOC) compounds into the water column and thus represent one of the major sources of potentially labile DOC (Biddanda \& Benner 1997, Marañón et al. 2004). This freshly released DOC can represent an important source of energy and nutrients to heterotrophic bacteria and the microbial loop (Baines \& Pace 1991, Legendre \& Rassoulzadegan 1996), and so it seems logical that there should be a link between a major source (phytoplankton photosynthesis) and a major sink (heterotrophic bacterioplankton). In their cross system overview of the apparent coupling between BP and particulate primary production (POCp), Cole et al. (1988) showed that these 2 processes are indeed linked, with BP increasing with POCp. Moreover, Moràn et al. (2002a) recently examined relationships between dissolved primary production (DOCp) and bacterial carbon demand (BCD) in a cross system comparison, and showed that while BCD was correlated with DOCp in oligotrophic regions, this relationship was either weak or non-existent in eutrophic systems.

Although total concentrations of DOC vary widely among ecosystems, it is estimated that only a small fraction of DOC is highly labile (utilizable on the scale of minutes to hours) and that the rest comprises an 
array of compounds with varying degrees of lability and recycling time (Carlson \& Ducklow 1996). Two recent reviews have provided comprehensive summaries that highlight the importance of DOC released during photosynthesis (Carlson 2002, Bertilsson \& Jones 2003). Despite recent increases in the number of DOCp measurements (e.g. Karl et al. 1998, Marañón et al. 2004), interest has tended to focus on rates of DOCp and the underestimation of primary production rates when the dissolved fraction is not taken into account, rather than on the fate of newly produced DOC and its impact on the microbial loop. Indeed, Bertilsson \& Jones (2003) recently commented on the need for more measurements focused on the 'functional links between heterotrophic microorganisms and primary producers'.

It is an accepted idea that newly produced DOC (DOCp) should be labile to bacteria; however, this hypothesis remains to be tested on a variety of phytoplankton groups and species assemblages. It has been known for some time that different phytoplankton species have different rates of carbon fixation per unit chlorophyll, and different nutrient requirements for growth. Moreover, the rates and types of organic carbon moieties released during photosynthesis are also known to differ between different phytoplankton groups (Biddanda \& Benner 1997, Biersmith \& Benner 1998, Carlson 2002): even on a simple, visual level, the differences between mucous-producing species such as Phaeocystis spp. and Trichodesmium spp. and nonmucous-producing species are easily recognizable. However, despite an increasing amount of evidence to indicate that there are large differences in the rates and types of compounds released by different phytoplankton species, little is known about the effect of these exudates on associated heterotrophic bacterial populations.

In tropical and sub-tropical waters, the cyanobacterium Trichodesmium spp. can often dominate phytoplankton assemblages, particularly in oligotrophic regions (Carpenter 1983). Despite the apparent ubiquity of this cyanobacterium in warmer waters, and perhaps as a consequence of the random nature of blooms, Trichodesmium spp. was for many decades considered as a minor player in the biogeochemical cycling of carbon and nitrogen in the oceans (Dugdale \& Goering 1967). This idea has recently been challenged, and it has been revealed that Trichodesmium spp. activity can be responsible for a major proportion of organic matter production in oligotrophic regions (Capone 2001, Michaels et al. 2001). Nevertheless, although many investigations have focused on the nitrogen fixing properties of this cyanobacterium, few have concentrated on the fate of the organic matter produced during photosynthesis (Hawser et al. 1992, O'Neil 1998), or on the production of DOC during photosyn- thesis (Shimura et al. 1978). Furthermore, few studies have examined the subsequent bioavailability of this freshly produced, and potentially labile, DOC to heterotrophic bacteria (e.g. Paerl et al. 1989)

Here we present the results of an investigation into the effects of photosynthetic exudates of natural samples of the colonial cyanobacterium Trichodesmium spp. on surrounding heterotrophic bacterial populations. We were able to sample the phytoplanktonic community present before, during, and after an accumulation of the colonial cyanobacterium Trichodesmium spp., which enabled us to determine: (1) the rates of both DOCp and POCp, and the relative percentage of DOCp of total primary production (TOCp) (percentage extracellular release: PER); and, (2) the effects of this freshly produced DOC on surrounding heterotrophic bacterial populations.

\section{MATERIALS AND METHODS}

Sampling site. Our sampling site was located in the outer parts of the bay of St. Marie in the southwestern lagoon of New Caledonia (Fig. 1a). Samples were collected 2 to 3 times wk ${ }^{-1}$ throughout March 2004 using a $35 \mu \mathrm{m}$ plankton net. Plankton tows were conducted early in the morning before the onset of the trade winds to take advantage of the calmer waters during which Trichodesmium spp. accumulate at the surface. Dependent upon the abundances observed, between 6 and 10 samples were collected and were returned to the laboratory in acid cleaned $(10 \% \mathrm{HCl})$ and Milli-Q rinsed 41 polycarbonate bottles. Samples were kept in a cooler during storage and transit.

During the second half of the month, a large accumulation of Trichodesmium spp. was found within the sampling area. The extremely high biomass observed meant that due to clogging of the net by the mucous matrix, samples were collected directly into several 41 polycarbonate bottles. Upon return to the laboratory, never more than 90 min after the first sampling, samples were transferred into a decanting ampoule of 41 volume after pre-filtration through a $100 \mu \mathrm{m}$ screen. The positive buoyancy of Trichodesmium spp. resulted in accumulation of this phytoplankton at the surface, and a light source directed towards the lower half of the ampoule aided the removal of most copepods present in the sample through a tap at the bottom. The decanting method, although less precise than collecting the individual colonies with an inoculating loop, permitted a more rapid and less physiologically stressed concentration of the sample.

High abundances of Trichodesmium spp. during the second half of the month meant that concentration of the samples was not necessary; therefore, samples 


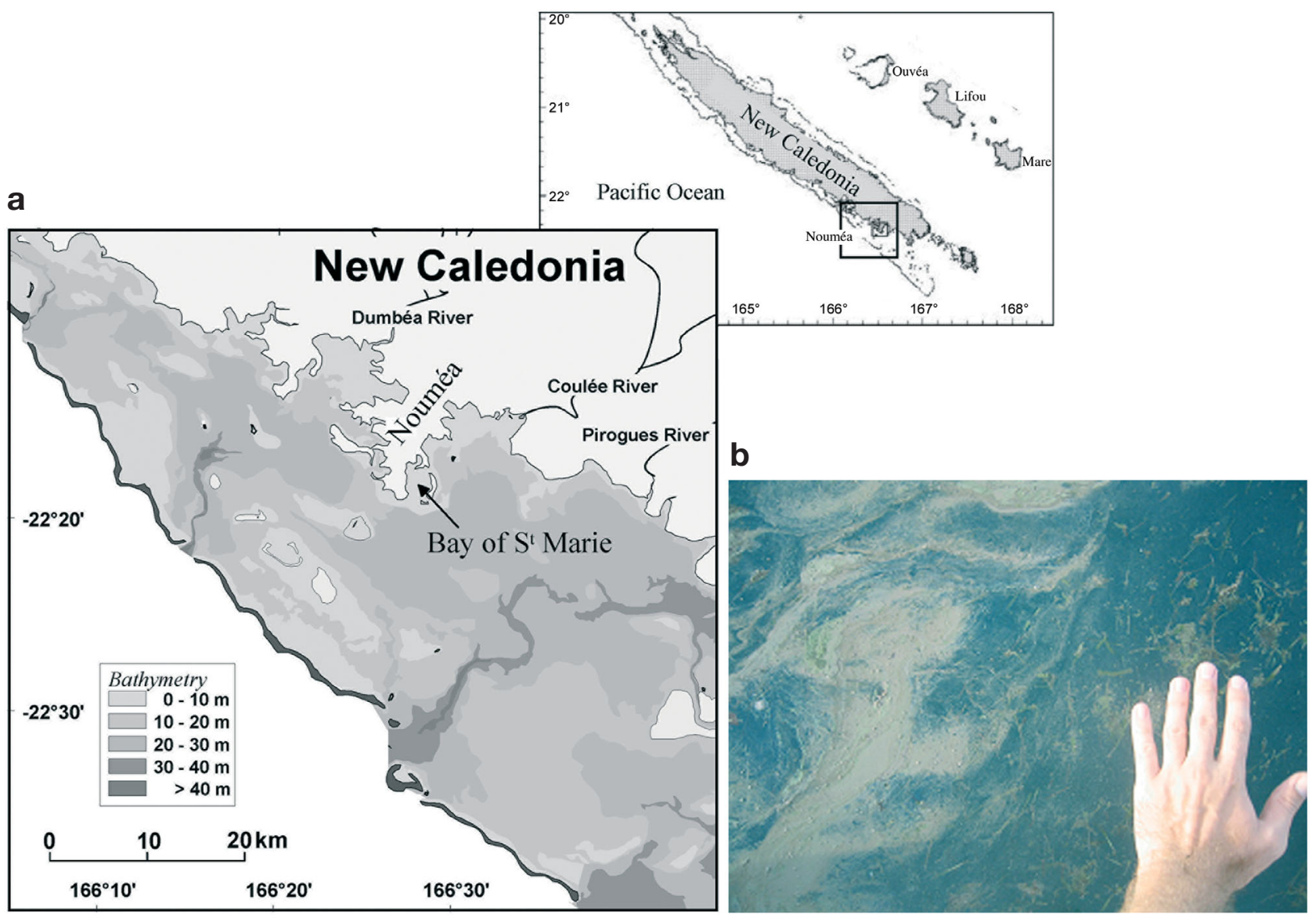

Fig. 1. (a) Study site. (b) Accumulation of Trichodesmium spp. at the water surface. Photograph taken on 24 March, which corresponded to the maximum Trichodesmium spp. abundance observed during the 1 mo survey

were pre-filtered through a $100 \mu \mathrm{m}$ screen to remove the larger particles before transferal into the decanting ampoule to facilitate distribution of the samples into experimental flasks. The content of the ampoule was then carefully divided between 3 identical incubation flasks (Fig. 2). The flasks were double-walled to allow control of the incubation temperature via a temperature-controlled re-circulating water bath. Each flask held $202 \mathrm{ml}$ and was closed by a silicone rubber stopper to ensure air-tightness. All incubations were initiated in the morning, upon return to the laboratory.

Primary production. Primary production was measured in Flask 1 (Fig. 2) using the ${ }^{14} \mathrm{C}$ method. For each incubation, ${ }^{14} \mathrm{C}$-bicarbonate was added to the flask to achieve a final concentration of $0.75 \mathrm{MBq} \mathrm{ml}^{-1}$. The flask was
Light incubation
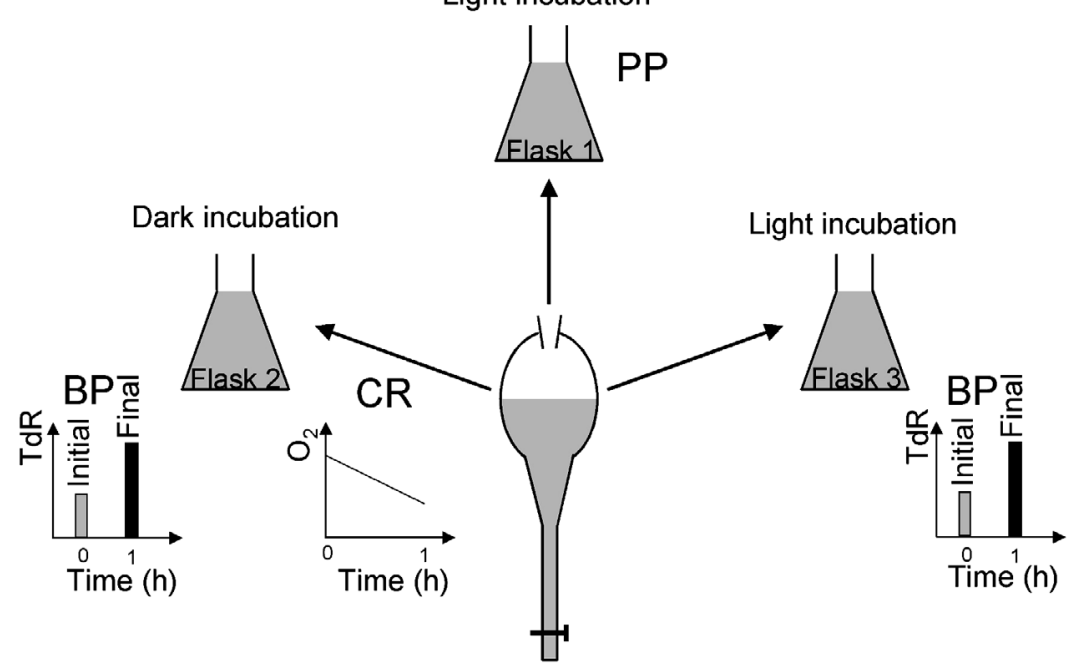

Fig. 2. Diagram of experimental protocol. After decantation, water was distributed into 3 flasks in order to measure bacterial production (BP), primary production (PP), and community respiration (CR). Inset graphs represent units of measurement over time (CR: $\mathrm{O}_{2}$ consumption; BP: [methyl $\left.{ }^{3} \mathrm{H}\right]$ thymidine [TdR] incorporation) for respective parameters 
then incubated in the light at in situ temperatures $\left( \pm 1^{\circ} \mathrm{C}\right)$ for $1 \mathrm{~h}$. Light was provided by an incandescent lamp and incubations were performed at $550 \mu \mathrm{mol}$ photons $\mathrm{m}^{-2} \mathrm{~s}^{-1}$. After $1 \mathrm{~h}, 25 \mathrm{ml}$ of sample was filtered (Whatman filter GF/F) for estimation of incorporation of the isotope into the particulate fraction (i.e. POCp). After acidification and drying, $5 \mathrm{ml}$ of scintillation cocktail (Ultima Gold MV, Packard) was added to the filters. For measurement of DOCp, $5 \mathrm{ml}$ of the filtrate was acidified with $100 \mu \mathrm{l} 50 \% \mathrm{HCl}$, and left in open vials for $12 \mathrm{~h}$ on an orbital shaker to remove any unused ${ }^{14} \mathrm{C}$-bicarbonate. After removal of the inorganic carbon, $15 \mathrm{ml}$ of scintillation cocktail (Ultima Gold XR, Packard) was added. Samples were then counted on a Tri-Carb Scintillation Counter (Packard). All measures were conducted in duplicate. The TOCp was calculated from addition of the rates of POCp and DOCp. The PER was calculated from:

$$
\mathrm{PER}=\frac{\mathrm{DOCp}}{\mathrm{DOCp}+\mathrm{POCp}} \times 100
$$

Bacterial production. BP was estimated at the beginning and end of each incubation in Flasks 2 and 3 (Fig. 2) by [methyl- $\left.{ }^{3} \mathrm{H}\right]$ thymidine (TdR) incorporation (1.44 $\mathrm{TBq} \mathrm{mol}{ }^{-1}$ ) (Amersham) according to Fuhrman \& Azam (1982) as modified by Torréton \& Dufour (1996). Rates of ${ }^{3} \mathrm{H}-\mathrm{TdR}$ incorporation were converted to production in terms of carbon using a conversion factor of $2.91 \times 10^{18}$ cells mol $^{-1} \mathrm{TdR}$ (S. Jacquet unpubl. data) and carbon conversion factor of $12.4 \mathrm{fg} \mathrm{C}^{\mathrm{C}} \mathrm{cell}^{-1}$ (Fukuda et al. 1998).

BP was measured in both dark and light flasks, in order to test the hypothesis that primary production stimulates bacterial activity as suggested by Church et al. (2004). Prior to incubation, initial BP was measured; samples were then incubated in the dark (Flask 2) and in the light (Flask 3) (Fig. 2) for $1 \mathrm{~h}$. At the end of the incubation, BP was again measured in both samples and compared to the initial value. The initial BP measurement was performed to assess the impact of the bottle effect on BP.

Community respiration. Community respiration (CR) was measured in the dark (Flask 2) using an oxygen microprobe, according to the procedure described by Briand et al. (2004). Oxygen concentration was continuously monitored during the incubation of $60 \mathrm{~min}$. Respiration was then computed from the slope of $\mathrm{O}_{2}$ vs. time and converted to carbon consumption using a respiratory quotient of 1 .

Chlorophyll concentration and phytoplankton abundances. Chlorophyll a ( $\mathrm{chl} \mathrm{a}$ ) concentration was estimated in duplicate in Flasks 2 and 3 at the beginning of the incubation. After filtration of $20 \mathrm{ml}$ onto a $25 \mathrm{~mm}$ GF/F filter, pigment concentrations (chl $a$ and phaeopigments) were determined fluorometrically (Turner
TD700) according the formula of Lorenzen (1966) as modified by Jeffrey \& Humphrey (1975).

Planktonic cell abundance (Trichodesmium spp., other phytoplankton, zooplankton, and bacterioplankton) was also estimated. Immediately after filling the incubation flasks, a $20 \mathrm{ml}$ aliquot of the sample was preserved with $0.2 \mu \mathrm{m}$ pore-size filtered boraxbuffered formalin ( $2 \%$ final concentration). Phytoplankton and zooplankton abundances were estimated using the Utermöhl method (Utermöhl 1958) with a $10 \mathrm{ml}$ sedimentation column (Hydro-Bios), after a sedimentation period of $24 \mathrm{~h}$. The entire slide was counted using an inverted microscope (Leitz Fluovert, magnification $\times 125$ ). The number of Trichodesmium spp. cells (counted individually and not as trichomes) was differentiated from other phytoplanktonic groups and zooplankton (mainly copepods and ciliates).

Bacterial abundance was measured by a direct count method using epifluorescent microscopy and DAPIstained samples (Porter \& Feig 1980); $10 \mathrm{ml}$ samples were stained with $0.2 \mu \mathrm{m}$ filtered DAPI solution for $10 \mathrm{~min}$ before filtering onto a black $0.2 \mu \mathrm{m}$ pore size Nuclepore filter. Filters were mounted on slides with non-fluorescent immersion oil and stored frozen until enumeration. For enumeration, at least 20 to 30 randomly selected microscope fields on each filter were counted with a Leitz Laborlux D at a magnification of $\times 1250$.

Statistics. Linear regression, correlation analysis and $t$-tests were used to determine relationships between variables. Relationships were considered significant when $\mathrm{p}<0.05$.

\section{RESULTS}

\section{Phytoplankton and bacterioplankton abundance}

During March (late austral summer), 2 main phytoplankton populations were observed. Microscopic observation of samples from the first half of the month revealed the presence of a mixed phytoplankton assemblage that was dominated by diatoms of the Chaetoceros genus. The abundance of Trichodesmium spp. in the samples was low during this period, and did not exceed $10 \%$ of the total phytoplankton cells (Fig. 3a). During the second half of the month, Trichodesmium spp. became the dominant phytoplankton and represented up to $98 \%$ of the phytoplankton community in the samples. Due to a period of calm weather, dense accumulations of Trichodesmium spp. were observed at the water surface (Fig. 1b). These accumulations covered approximately several hundred square meters and persisted up to 1 April. After 1 April, the sampling area was exposed to strong trade 

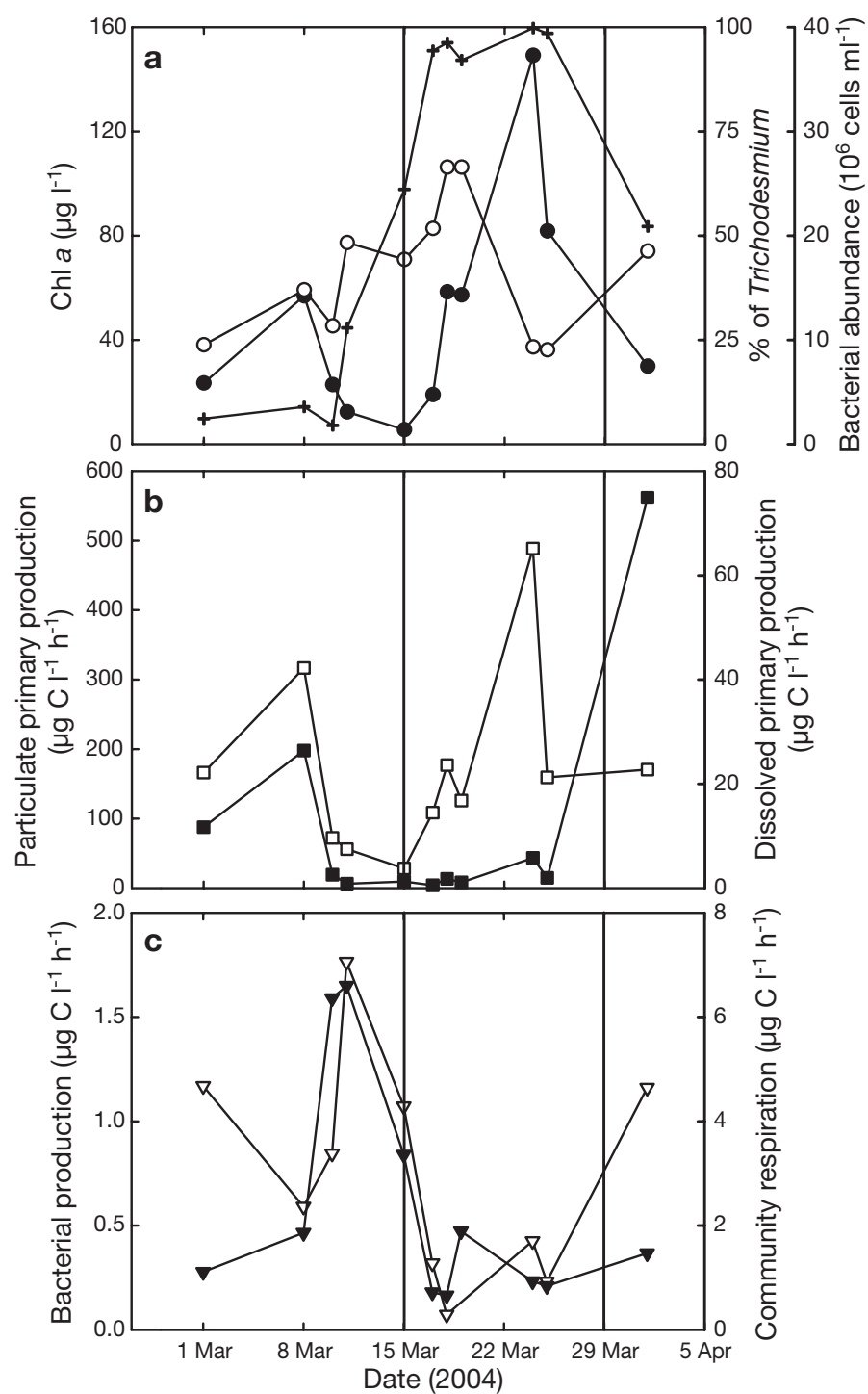

Fig. 3. Abundance and activity over time during 1 mo survey. (a) Chl a concentration $(\bullet)$, bacterial abundance ( $(0)$, and proportion of Trichodesmium spp. (\% total phytoplankton cells) (+). (b) Particulate (POCp: ם) and dissolved (DOCp: $\square)$ primary production. (c) Bacterial production (BP: $\nabla$ ) and community respiration (CR: $\mathbf{\nabla})$. Note difference in scales between $y$-axes. Vertical lines separate different phases of the bloom during the 1 mo survey: pre-bloom, bloom and bloom collapse, respectively

winds (above 20 knots) leading to a total disappearance of the bloom due to strong mixing of the water column. We therefore arbitrarily divided the sample period as a function of the 2 different phytoplankton communities observed. Thus, hereafter, we refer to those samples collected before 15 March as belonging to the mixed community, and those from the second half of the month as belonging to the Trichodesmium spp. dominated community.

Bacterial abundances varied with time. Lowest values (around $9.3 \times 10^{6}$ cells $\mathrm{ml}^{-1}$ ) were observed con- comitant with the maximum of relative Trichodesmium spp. abundance and chl a concentration (Fig. 3a). Prior to the Trichodesmium spp. bloom, bacterial abun-

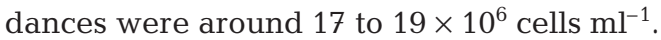

\section{Primary production and bacterial production}

Particulate primary production (POCp) was always higher than DOCp (Fig. 3b); POCp varied by a factor of 17 and ranged between 28 and $488 \mu \mathrm{g} \mathrm{Cl}^{-1} \mathrm{~h}^{-1}$, reflecting the wide range of chl a concentrations observed (5 to $149 \mathrm{\mu g} \mathrm{l}^{-1}$ ) in the concentrated samples used for incubations. DOCp rates were up 200 times lower than POCp rates; however, the range of variation was much larger than that of POCp. At the beginning of the month, DOCp rates were relatively high (11.7 and $26.4 \mu \mathrm{g} \mathrm{Cl}^{-1} \mathrm{~h}^{-1}$, for 1 and 8 March, respectively); rates

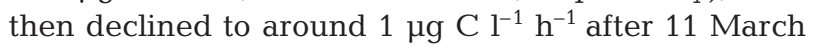
and remained low until 1 April, when a rate of $74 \mu \mathrm{g} \mathrm{C}$ $\mathrm{l}^{-1} \mathrm{~h}^{-1}$ was observed. This high DOCp rate was concomitant with the decline of the bloom (Fig. 3b). BP and CR (Fig. 3c) exhibited maximum rates around 10 March with values of 1.76 and $6.6 \mu \mathrm{g} \mathrm{C}^{-1} \mathrm{~h}^{-1}$, respectively. During the bloom of Trichodesmium spp., both metabolic processes strongly decreased to reach the lowest values observed during the 1 mo survey $(0.07$ and $0.66 \mu \mathrm{g} \mathrm{Cl}^{-1} \mathrm{~h}^{-1}$ for BP and CR, respectively). After the decline of the bloom, BP and CR increased again, with $\mathrm{BP}$ exhibiting a larger increase.

TOCp, calculated from the sum of POCp and DOCp, was correlated with chl a for both communities (Fig. 4a). Interestingly, TOCp rates were significantly higher ( $t$-test, $\mathrm{p}<0.01)$ per unit chl $\mathrm{a}$ in the mixed community (slope of regression: $6.2 \mu \mathrm{g} \mathrm{C} \mu \mathrm{g} \mathrm{chl} a^{-1} \mathrm{~h}^{-1}, \mathrm{r}=$ 0.96, $\mathrm{p}<0.01$ ) than in the Trichodesmium spp. community $\left(2.9 \mu \mathrm{g} \mathrm{C} \mu \mathrm{g} \mathrm{chl} \mathrm{a}^{-1} \mathrm{~h}^{-1}, \mathrm{r}=0.94, \mathrm{p}<0.01\right)$. In other words, chl a normalized primary production (assimilation number) was higher in the mixed community and declined with increasing Trichodesmium spp. dominance $(r=0.79, p<0.01)$ Thus, for the same chl a concentration, the Trichodesmium spp. community fixed half as much carbon as the mixed community.

In terms of POCp and DOCp and their relative proportions to TOCp, there were also differences between the 2 communities (Fig. 4b). Rates of DOCp were relatively higher in the mixed community than in the Trichodesmium spp. dominated community. For example, at the beginning of March we observed a POCp of $166 \mu \mathrm{g} \mathrm{Cl}^{-1} \mathrm{~h}^{-1}$ and a DOCp of $12 \mu \mathrm{g} \mathrm{C}^{-1} \mathrm{~h}^{-1}$, whereas on $18 \mathrm{March}^{-}$during the period of Trichodesmium spp. dominance, for a very similar POCp of $177 \mu \mathrm{g} \mathrm{C}^{-1} \mathrm{~h}^{-1}$ we observed DOCp rates of only $1.8 \mu \mathrm{g} \mathrm{Cl}^{-1} \mathrm{~h}^{-1}$. DOCp was positively correlated with POCp $(r=0.99, p<0.001$ for the mixed community and $r=0.94, p<0.01$ for the 

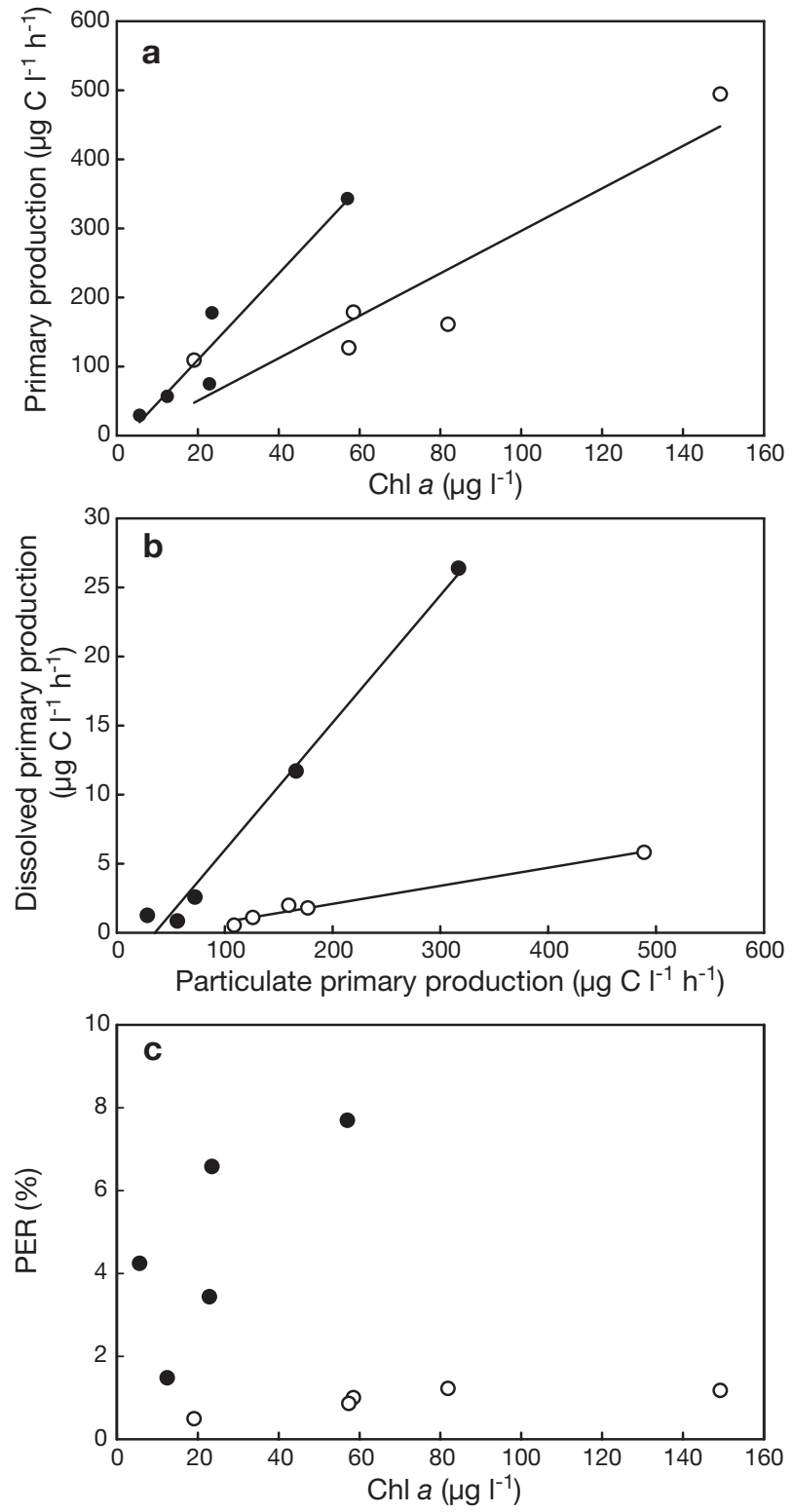

Fig. 4. Primary production and chl $a$, both communities. (a) Total primary production $(\mathrm{TOCp}=\mathrm{POCp}+\mathrm{DOCp})$ as a function of chl a concentration. Slopes of lines represent average assimilation index of each community $\left(\mu \mathrm{g} \mathrm{C} \mu \mathrm{g} \mathrm{chl} a^{-1}\right.$ $\mathrm{h}^{-1}$ ). (b) Relationship between POCp and DOCp. (c) Relationship between chl $a$ and percentage of extracellular release (PER). •: Mixed community; o: Trichodesmium spp. dominated community

Trichodesmium spp. community) in both communities with a slope of 0.09 and 0.01 for the mixed community and Trichodesmium spp. community, respectively. In other words, for the same carbon production, the Trichodesmium spp. community released almost 10 -fold less dissolved organic matter (DOM) than the mixed community. This reduction in the proportion of DOCp relative to POCp translated into a decrease in the relative PER. Thus, it was clear that the PER was not constant between the 2 communities; furthermore, this difference was visible over a range of chl a concentrations (Fig. 4c).

In the mixed community, BP was strongly correlated $(\mathrm{r}=0.93, \mathrm{p}<0.05)$ with phytoplankton abundance. In contrast, during the Trichodesmium spp. bloom, no significant correlation $(r=0.36, p=0.55)$ was observed between BP and Trichodesmium spp. abundance (Fig. 5a). The degree of stimulation of BP over the $1 \mathrm{~h}$ incubation (in terms of percentage stimulation relative to BP at the start of the incubation) is shown in Fig. 5b. At the beginning of March, BP was stimulated by up to $380 \%$ during the incubation, whereas during the second half of the month (the period corresponding to the

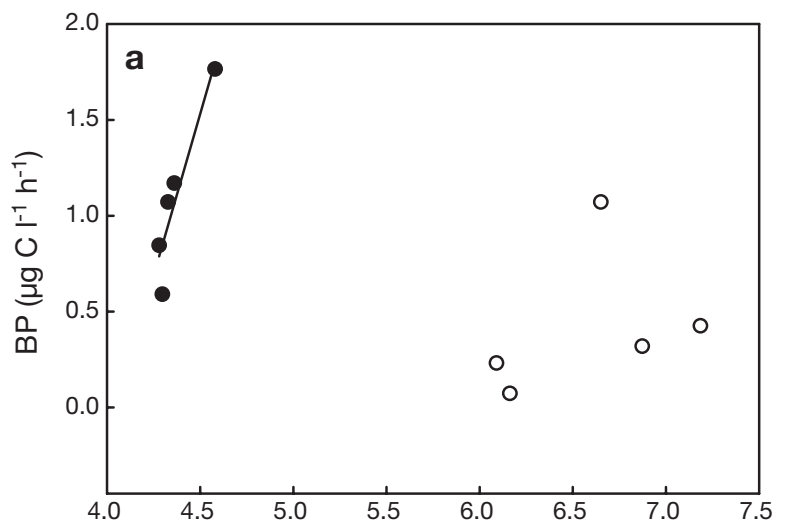

Phytoplankton or Trichodesmium abundance (log cell I-1)

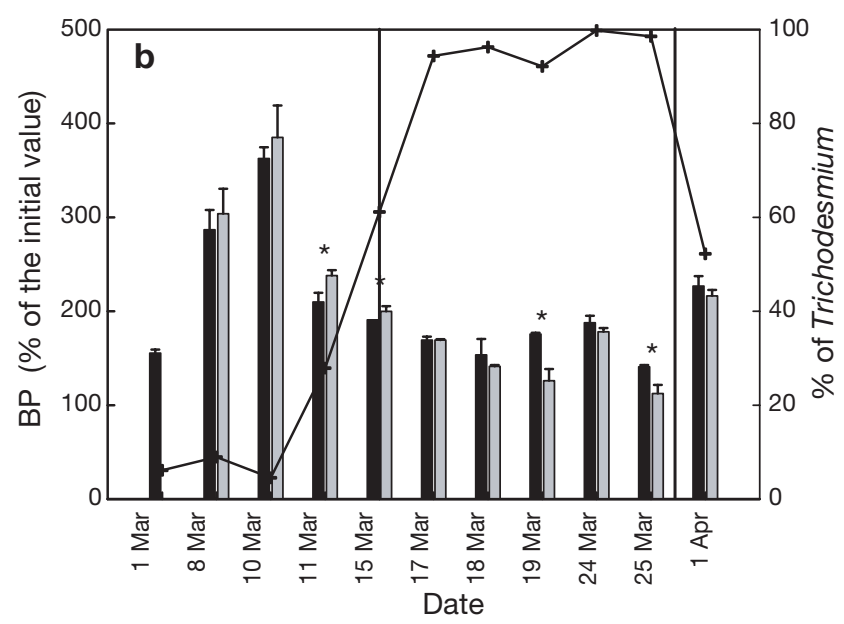

Fig. 5. (a) Bacterial production (BP) as a function of phytoplankton and Trichodesmium spp. abundance; $\bullet$ : mixed community; o: Trichodesmium spp. dominated community. (b) Percentage stimulation of BP over $1 \mathrm{~h}$ incubation as a function of light conditions; black bars: dark incubations (Flask 2); light grey bars: light incubations (Flask 3). Relative abundance of Trichodesmium spp. also shown (+). Vertical lines separate different phases of the bloom during the 1 mo survey: prebloom, bloom and bloom collapse, respectively; *: significant differences $(p<0.05)$ between light and dark incubations 
highest Trichodesmium spp. abundance) the percentage stimulation was considerably lower and was on average $155 \pm 24 \%$ (Fig. 5 a). Furthermore, in both the dark and the light incubations, the percentage stimulation of BP decreased with increasing Trichodesmium spp. abundance (Fig. 5b). During the first half of the incubation, BP was generally higher in the light than in the dark and was significantly higher $(t$-test, $\mathrm{p}<0.05)$ on 11 and 15 March (Fig. 4b). In contrast, during the period of Trichodesmium spp. dominance, BP rates tended to be lower during the light incubation (and hence during active photosynthesis) than in the dark incubation. Indeed, rates were significantly lower ( $t$-test, $\mathrm{p}<0.05$ ) on 19 and 25 March (Fig. 4b).

\section{DISCUSSION}

The PER, assimilation number, and bacterial activity and degree of stimulation showed that structural changes in phytoplankton community composition led to functional changes that were measurable in terms of carbon cycling during the 1 mo period of sample collection. We observed 2 main phytoplankton communities in our net samples. In the first community-the mixed, mostly diatom dominated assemblage-primary production and PER rates and assimilation numbers were higher than in the second, Trichodesmium spp. dominated community.

The collection of Trichodesmium spp. samples by plankton net is a frequently used method; indeed, it is perhaps the only effective way of collecting sufficient colonies during periods of low abundance. We therefore used this method during the first half of the sampling in order to attain sufficient biomass. However, during the second half of the sampling period, the appearance of a large accumulation of Trichodesmium spp. in the sample area meant that net sampling was neither necessary nor possible; consequently, samples were collected directly into 41 polycarbonate bottles. Thus, while it can be considered that phytoplankton abundances and, hence, chl a concentrations were higher during the first half of the sampling period than is normally observed in this area, the abundances observed during the second half of the month can be considered as representative of in situ concentrations within a bloom.

We observed trichome and chl a concentrations of up to $150 \mathrm{ml}^{-1}$ and $150 \mathrm{\mu g} \mathrm{l}^{-1}$, respectively, at the peak of the bloom. These values are comparable to those reported by Carpenter \& Capone (1992) for trichome abundance within blooms (average of 100 trichomes $\mathrm{ml}^{-1}$ ), and are well within the range reported by Karl et al. (1992), who observed chl a concentrations of up to $1168 \mathrm{\mu g} \mathrm{l}^{-1}$ in the North Pacific. Furthermore, the assimilation index (chl a normalized primary production) calculated during the Trichodesmium spp. bloom $\left(2.9 \mu \mathrm{g} \mathrm{C} \mu \mathrm{g} \mathrm{chl} a^{-1} \mathrm{~h}^{-1}\right)$ is comparable to the assimilation index estimated by Paerl (1994) and by Letelier \& Karl (1996), who observed values around 2.5 to $3.5 \mu \mathrm{g} \mathrm{C} \mu \mathrm{g} \mathrm{chl} a^{-1} \mathrm{~h}^{-1}$ for both natural and cultured populations.

Although our rates of PER were low for both communities, they fell within the ranges reported by Nagata (2000) and Morán et al. (2002b), and our average PER value of $8 \%$ in the community dominated by diatoms was close to that of Morán et al. (2002b), who observed PER production values of around $7 \%$ in the northeast Atlantic Ocean. Previously reported measurements of DOM released by Trichodesmium spp. are higher (ca. 8\%) (Shimura et al. 1978) than the value that we calculated for the community dominated by Trichodesmium spp. (ca. 1\%); however, the reason for this difference could be due to several factors, some of which are methodological. As outlined by several authors (Karl et al. 1998, Morán \& Estrada 2001, Marañón et al. 2004), a number of precautions need to be observed when measuring DOCp. Sufficiently high concentrations of radioactivity are required to ensure a good sample to blank ratio (in this study the average ratio was 2.6), short incubation times are necessary to avoid too much recycling of DOCp (Gilbert \& Bronk 1994), and incubations should be terminated by simple filtration to avoid the use of fixatives that are known to induce large amounts of DOC release (up to $78 \%$ of the PER) (Shimura et al. 1978). Finally, although our use of GF/F filters in this study may have resulted in an underestimation of the DOCp (Karl et al. 1998, Morán et al. 1999), this underestimation was probably the same for both communities, as the same method was used. Therefore, in a comparative sense, it is still evident that release rates were lower in the Trichodesmium spp. community. Furthermore, even if GF/F filtration did significantly decrease the PER values, the apparent suppression of bacterial activity in the Trichodesmium spp. incubations remained unaffected by this methodological problem.

We observed a decrease in bacterial activity and CR with increasing Trichodesmium spp. dominance. Furthermore, both parameters remained low during the persistence of the bloom (Fig. 2c). Indeed, at the end of the bloom we observed very high levels of DOCp (72 $\mu \mathrm{g} \mathrm{C} \mathrm{l}^{-1} \mathrm{~h}^{-1}$ ) in incubations that were coincident with the lowest values of BP and CR (Fig. 3c). Sellner (1997) previously reported decreases in bacterial abundance and activity during a bloom of the cyanobacteria Aphanizomenon sp. We also observed parallel decreases in bacterial activity and abundance; however, these 2 parameters were not significantly correlated in our data set $\left(R^{2}=0.0032\right)$. Thus, the decrease in 
BP was not wholly due to a decrease in bacterial abundance and was probably due, at least in part, to a decrease in the proportion of active bacteria. Additionally, dark CR was lowest during the period of highest Trichodesmium spp. dominance, similar to that of BP (Fig. 3c), which suggested a potential inhibition of the heterotrophic community. This apparent inhibition of bacterial activity was also noted by Nausch (1996), who observed higher bacterial activities in the surrounding water than within Trichodesmium spp. colonies. In addition, for those light and dark incubations that were statistically significantly different, we observed lower $\mathrm{BP}$ in the light relative to dark incubations in the Trichodesmium spp. dominated samples (Fig. 5b).

The inverse was true in the mixed community. The latter observation was in agreement with the study of Church et al. (2004), who observed in the North Tropical gyre that BP, measured by ${ }^{3} \mathrm{H}$-leucine, was strongly stimulated by light indicating a tight coupling between primary production and BP. Conversely, the apparent inhibition of BP in light, as observed for the Trichodesmium spp. community, was supported by the observation of Moràn et al. (2001), who reported that BP in the Mediterranean waters was strongly inhibited by light. Our results confirmed that the effects of light on BP is dependent on the environment as well as on both phytoplankton and bacterial structure, as suggested by Church et al. (2004). In addition, the apparent inhibition of bacterial activity in the Trichodesmium spp. dominated community could be due to low DOCp from the cyanobacteria. This was probably not the sole reason for lower bacterial activities, as BP in the dark control with lower DOCp concentrations was higher than that in the light. An alternative explanation is perhaps that the quality or 'bioavailability' of exudates produced by Trichodesmium spp. was lower. Many cyanobacteria are known to release toxic compounds that are inhibitory or toxic to both vertebrates and invertebrates (Codd 1999): e.g. the cyanobacterium Nodularia spumigena produces the toxin Nodularin, which has been shown to be resistant to bacterial degradation (Mazur \& Plinski 2001). Care needs to be taken when interpreting our results due to the small data set available.

Despite being potential sources of inhibitory compounds, cyanobacterial colonies are known to have a complex mix of associated bacterial symbionts (Paerl \& Pinckney 1996). Colonies of Nodularia spumigena have been shown to possess at least 13 bacteria strains (Salomon et al. 2003). Similarly, Trichodesmium spp. are associated with a wide range of microbes that includes bacteria, dinoflagellates, amoebae, ciliates, and diatoms (Sheridan et al. 2002). Moreover, it is also probable that free bacteria and filament-associated bacteria differ in terms of their diversity and physio- logical activity (Paerl \& Pinckney 1996, Salomon et al. 2003). Thus, if we can assume that associated bacteria obtain some benefits from association with cyanobacteria, for example the transfer of organic matter and nutrients (Paerl et al. 1989), it would appear, at least in this data set, that any benefit obtained comes at the price of lower activities. Lower rates of TdR uptake within colonies have also been observed by Nausch (1996) and are in accordance with the results of Alldredge et al. (1986), who observed reduced bacterial activities on marine snow particles. We measured TdR uptake on whole water samples and so therefore took into account the uptake rates of the entire bacterial pool and not just of colony-associated bacteria; thus, when considering the results of Nausch (1996), it is possible that during a Trichodesmium spp. bloom bacterial activity is reduced both in the colony-associated bacteria and within free bacteria. However, as we have no abundance estimates of associated bacteria, or any measure of their diversity or specific activity, these hypotheses remain difficult to elucidate. Nevertheless, our study, which included the entire bacterial pool, may better reflect what happens in the field during a bloom. Lastly, although the presence of a consortium of associated bacteria within the Trichodesmium spp. colony may partly explain the small observed values of DOCp and PER (through rapid transfer and recycling), this cannot be the sole explanation. Indeed, if there was a rapid recycling of DOCp by the bacteria, we would have observed elevated bacterial activity levels in the entire bacterial pool instead of the converse.

The apparent inhibition of bacterial activity by Trichodesmium spp. may have important implications for the cycling of carbon in open ocean areas. The low bacterial activity and $\mathrm{CR}$ rates observed during the bloom suggests that organic matter fixed by these cyanobacteria is removed from the water column by a mechanism other than bacterial uptake and remineralisation, such as through coagulation and sedimentation (X. Mari et al. unpubl. data). However, if the composition of organic matter produced by Trichodesmium spp. changes throughout the development and decline of the bloom, as has been observed for other phytoplankton species (Biersmith \& Benner 1998, Mari et al. 2005), then the bioavailability of these exudates may not always be low. If this is the case, then the accumulation of non-utilizable DOM in the surface waters may only occur during active growth. As we only have 1 data point collected after the collapse of the bloom, it is difficult to draw any conclusions on this. Nevertheless, BP and CR were higher towards the end of the bloom, potentially indicating either an adaptation by the bacteria to the substrates and/or a reduction in the inhibitory compounds present. Undoubtedly, a more focused investigation on the fate of DOM produced 
during a Trichodesmium spp. bloom is required to address these questions.

Our study of primary production (POCp and DOCp) and of BP showed that the 2 communities were different in terms of photosynthetic efficiency, DOCp rates, and bioavailability of that DOCp to the surrounding heterotrophic bacterial population. The apparent inhibition of bacterial activity that we observed is contrary to what has been previously observed for other phytoplankton, and further highlights the need for more studies that examine the functional and structural nature of the relationships between phytoplankton and bacteria in the natural environment.

Acknowledgements. This research was funded by the French Institut de Recherche pour le Développement. Robert Leborgne is thanked for his help with the Trichodesmium counting.

\section{LITERATURE CITED}

Alldredge AL, Cole JJ, Caron DA (1986) Production of heterotrophic bacteria inhabiting organic aggregates (marine snow) from surface waters. Limnol Oceanogr 31:68-78

Baines SB, Pace ML (1991) The production of dissolved organic matter by phytoplankton and its importance to bacteria: patterns across marine and freshwater systems. Limnol Oceanogr 36:1078-1090

Bertilsson S, Jones JB (2003) Supply of dissolved organic matter to aquatic ecosystems: autochthonous sources. In: Findlay S, Sinsabaugh R (eds) Aquatic ecosystems: interactivity of dissolved organic matter. Academic Press, San Diego, CA, p 3-24

Biddanda BA, Benner R (1997) Carbon, nitrogen and carbohydrate fluxes during the production of particulate and dissolved organic matter by phytoplankton. Limnol Oceanogr 42:506-518

Biersmith A, Benner R (1998) Carbohydrates in phytoplankton and freshly produced dissolved organic matter. Mar Chem 63:131-144

Briand E, Pringault O, Jacquet S, Torréton JP (2004) The use of oxygen microprobes to measure bacterial respiration for determining bacterioplankton growth efficiency. Limnol Oceanogr Methods 2:406-416

Capone DG (2001) Marine nitrogen fixation: what's the fuss? Curr Opin Microbiol 4:341-348

Carlson CA (2002) Production and removal processes. In: Hansell DA, Carlson CA (eds) Marine dissolved organic matter. Academic Press, San Diego, CA, p 91-152

Carlson CA, Ducklow HW (1996) Growth of bacterioplankton and consumption of dissolved organic carbon in the Sargasso Sea. Aquat Microb Ecol 10:69-85

Carpenter EJ (1983) Nitrogen fixation by marine Oscillatoria (Trichodesmium) in the world's oceans. In: Capone DG, Carpenter EJ (eds) Nitrogen in the marine environment. Academic Press, New York, p 65-103

Carpenter EJ, Capone D (1992) Nitrogen fixation in Trichodesmium blooms. In: Carpenter EJ, Capone D, Rueter JG (eds) Marine pelagic cyanobacteria: Trichodesmium and other diazotrophs. Kluwer, Amsterdam, p 211-217

Church MJ, Ducklow HW, Karl DM (2004) Light dependence of $\left[{ }^{3} \mathrm{H}\right]$ leucine incorporation in the oligotrophic North Pacific Ocean. Appl Environ Microbiol 70:4079-4087

Codd GA (1999) Cyanobacterial toxins: their occurence in the aquatic environment and significance to health. In: Charpy L, Larkum A (eds) Marine cyanobacteria. Bull Inst Oceanogr Monaco 19:483-500

Cole J, Findlay S, Pace ML (1988) Bacterial production in fresh and saltwater ecosystems: a cross-system overview. Mar Ecol Prog Ser 43:1-10

Dugdale RC, Goering JJ (1967) Uptake of new and regenerated forms of nitrogen in primary productivity. Limnol Oceanogr 12:196-206

Fuhrman JA, Azam F (1982) Thymidine incorporation as a measure of heterotrophic bacterioplankton production in marine surface water: evaluation and field results. Mar Biol 66:109-120

Fukuda R, Ogawa H, Nagata T, Koike I (1998) Direct determination of carbon and nitrogen contents of natural bacterial assemblages in marine environments. Appl Environ Microbiol 64:3352-3358

Gilbert PM, Bronk DA (1994) Release of dissolved organic nitrogen by marine diazotrophic cyanobacteria, Trichodesmium sp. Appl Environ Microbiol 60:3996-4000

Hawser SP, O'Neil JM, Roman MR, Codd GA (1992) Toxicity of blooms of the cyanobacterium Trichodesmium to zooplankton. J Appl Phycol 4:79-86

Jeffrey SW, Humphrey GF (1975) New spectrophotometric equations for determining chlorophylls a, b, c1, c2 in algae, phytoplankton and higher plants. Biochem Physiol 167:191-194

Karl DM, Letelier RM, Hebel DV, Bird DF, Winn CD (1992) Trichosdesmium blooms and new nitrogen in the North Pacific Gyre. In: Carpenter E, Capone DG, Rueter JG (eds) Marine pelagic cyanobacteria: Trichodesmium and other diazotrophs. Kluwer, Amsterdam, p 219-238

Karl DM, Hebel DV, Björkman K, Letelier RM (1998) The role of dissolved organic matter release in the productivity of the oligotrophic North Pacific Ocean. Limnol Oceanogr 43:1270-1286

Legendre L, Rassoulzadegan F (1996) Food-web mediated export of biogenic carbon in oceans: hydrodynamic control. Mar Ecol Prog Ser 145:179-193

Letelier RM, Karl DM (1996) Role of Trichodesmium spp. in the productivity of the subtropical North Pacific Ocean. Mar Ecol Prog Ser 133:263-273

Lorenzen CJ (1966) A method for the continuous measurement of in vivo chlorophyll concentration. Deep-Sea Res 13:223-227

Marañón E, Cermeño P, Fernández E, Rodríguez J, Zabala L (2004) Significance and mechanisms of photosynthetic production of dissolved organic carbon in a coastal eutrophic ecosystem. Limnol Oceanogr 49:1652-1666

Mari X, Rassoulzadegan F, Brussaard CPD, Wassmann P (2005) Dynamics of transparent exopolymeric particles (TEP) production by Phaeocystis globosa under N- or Plimitation: a controlling factor of the retention/export balance? Harmful Algae 4:895-914

Mazur H, Plinski M (2001) Stability of cyanotoxins, microcystin-LR, microcystin-RR and nodularin in seawater and BG-11 medium of different salinity. Oceanologia 43: 329-339

Michaels AF, Karl DM, Capone DG (2001) Element stoichiometry, new production and nitrogen fixation. Oceanography 14:68-77

Morán XAG, Estrada M (2001) Short-term variability of photosynthetic parameters and particulate and dissolved primary production in the Alboran Sea (SW Mediter- 
ranean). Mar Ecol Prog Ser 212:53-67

Morán XAG, Gasol JM, Arin L, Estrada M (1999) A comparison between glass fiber and membrane filters for the estimation of phytoplanktonic POC and DOC production. Mar Ecol Prog Ser 187:31-41

Morán XAG, Massana R, Gasol JM (2001) Light conditions affect the measurement of oceanic bacterial production via leucine uptake. Appl Environ Microbiol 67: 3795-3801

Morán XAG, Gasol JM, Pedros-Alio C, Estrada M (2002a) Partitioning of phytoplanktonic organic carbon production and bacterial production along a coastal offshore gradient in the NE Atlantic during different hydrographic regimes. Aquat Microb Ecol 29:239-252

Morán XAG, Estrada M, Gasol JM, Pedros-Alio C (2002b) Dissolved primary production and the strength of phytoplankton-bacterioplankton coupling in contrasting marine regions. Microb Ecol 44:217-223

Nagata T (2000) Production mechanisms of dissolved organic matter. In: Kirchman DL (ed) Microbial ecology of the oceans. John Wiley \& Sons, New York, p 121-152

Nausch M (1996) Microbial activities on Trichodesmium colonies. Mar Ecol Prog Ser 141:173-181

O'Neil J (1998) The colonial cyanobacterium Trichodesmium as a physical and nutritional substrate for the harpacticoid copepod Macrosetella gracilis. J Plankton Res 20:43-59

Paerl HW (1994) Spatial segregation of $\mathrm{CO}_{2}$ fixation in Trichodesmium spp.: linkage to $\mathrm{N}_{2}$ fixation potential. J Phycol 30:790-799

Editorial responsibility: Edna Granéli, Kalmar, Sweden
Paerl HW, Pinckney JL (1996) A mini-review of microbial consortia: their roles in aquatic production and biogeochemical cycling. Microb Ecol 31:225-247

Paerl H, Bebout B, Prufert L (1989) Bacterial associations with marine Oscillatoria sp. (Trichodemsuim sp.) populations: ecophysiological implications. J Phycol 25:773-784

Porter KG, Feig YS (1980) The use of DAPI for identifying and counting aquatic microflora. Limnol Oceanogr 25:943-948

Salomon PS, Janson S, Granéli E (2003) Molecular identification of bacteria associated with filaments of Nodularia spumigena and their effect on the cyanobacterial growth. Harmful Algae 2:261-272

Sellner KG (1997) Physiology, ecology, and toxic properties of marine cyanobacteria blooms. Limnol Oceanogr 42: 1089-1104

Sheridan CC, Steinberg DK, Kling GW (2002) The microbial and metazoan community associated with colonies of Trichodesmium spp.: a quantitative survey. J Plankton Res 24:913-922

Shimura S, Yamaguchi Y, Aruga Y, Fujita Y, Ichimura S (1978) Extracellular release of photosynthetic products by a pelagic blue-green alga, Trichodesmium thiebautii. J Oceanogr Soc Jpn 34:181-188

Torréton JP, Dufour P (1996) Temporal and spatial stability of bacterioplankton biomass and productivity in an atoll lagoon. Aquat Microb Ecol 21:125-137

Utermöhl H (1958) Zur Vervollkommnung der quantitativen Phytoplankton-Methodik. Mitt Int Ver Theor Angew Limnol 9:1-38

Submitted: May 19, 2005; Accepted: September 7, 2005 Proofs received from author(s): December 20, 2005 